\title{
Bulk Shielding Facility Quarterly Report July, August, and September of 1976
}
S. S. Hurt, III
E. D. Lance
J. R. Thomas

\section{OAK RIDGE NATIONAL LABORATORY}




\section{DISCLAIMER}

This report was prepared as an account of work sponsored by an agency of the United States Government. Neither the United States Government nor any agency Thereof, nor any of their employees, makes any warranty, express or implied, or assumes any legal liability or responsibility for the accuracy, completeness, or usefulness of any information, apparatus, product, or process disclosed, or represents that its use would not infringe privately owned rights. Reference herein to any specific commercial product, process, or service by trade name, trademark, manufacturer, or otherwise does not necessarily constitute or imply its endorsement, recommendation, or favoring by the United States Government or any agency thereof. The views and opinions of authors expressed herein do not necessarily state or reflect those of the United States Government or any agency thereof. 


\section{DISCLAIMER}

Portions of this document may be illegible in electronic image products. Images are produced from the best available original document. 


\section{Printed in the United States of America. Available from}

Natiural Teclurical Iıfümation Service

U.S. Department of Commerce

5285 Port Royal Road, Springfield, Virginia 22161

Price: Printed Copy $\$ 4.00$; Microfiche $\$ 3.00$

This report was prepared as an account of work sponsored by the United States Government. Neither the United States nor the Energy Research and Development Administration/United States Nuclear Regulatory Commission, nor any of their employees, nor any of their contractors, subcontractors, or their employees, makes any warranty, express or implied, or assumes any legal liability or responsibility for the accuracy, completeness or usefulness of any information, apparatus, product or process disclosed, or represents that its use would not infringe privately owned rights. 
Contract No. W-7405-eng-26

OPERATIONS DIVISION

BULK SHIELDING FACILITY QUARTERLY REPORT

JULY, AUGUST, AND SEPTEMBER OF .1976

S. S. Hurt, III

E. D. Lance

J. R. Thomas

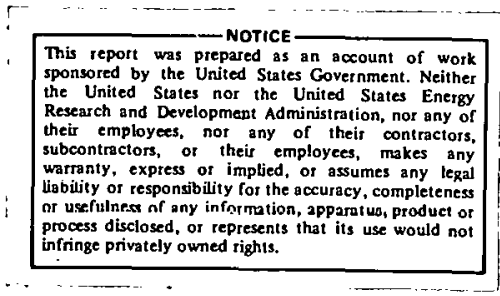

Date Published - June 1977

NOTICE This document contains information of a preliminary nature. It is subject to revision or correction and therefore does not represent a final report.

OAK RIDGE NATIONAL LABORATORY

\author{
Oak Ridge, Tennessee 37830 \\ operated by \\ UNION CARBIDE CORPORATION \\ for the \\ ENERGY RESEARCH AND DEVELOPMENT ADMINISTRATION
}

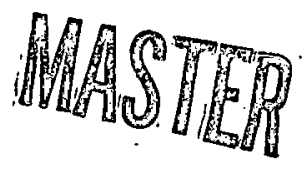

$$
\text { MISTRIBUTION OF. THIS QOOUMENT IS UNLIMITEO }
$$


THIS PAGE

\section{WAS INTENTIONALLY \\ LEFT BLANK}


CONTENTS

Page

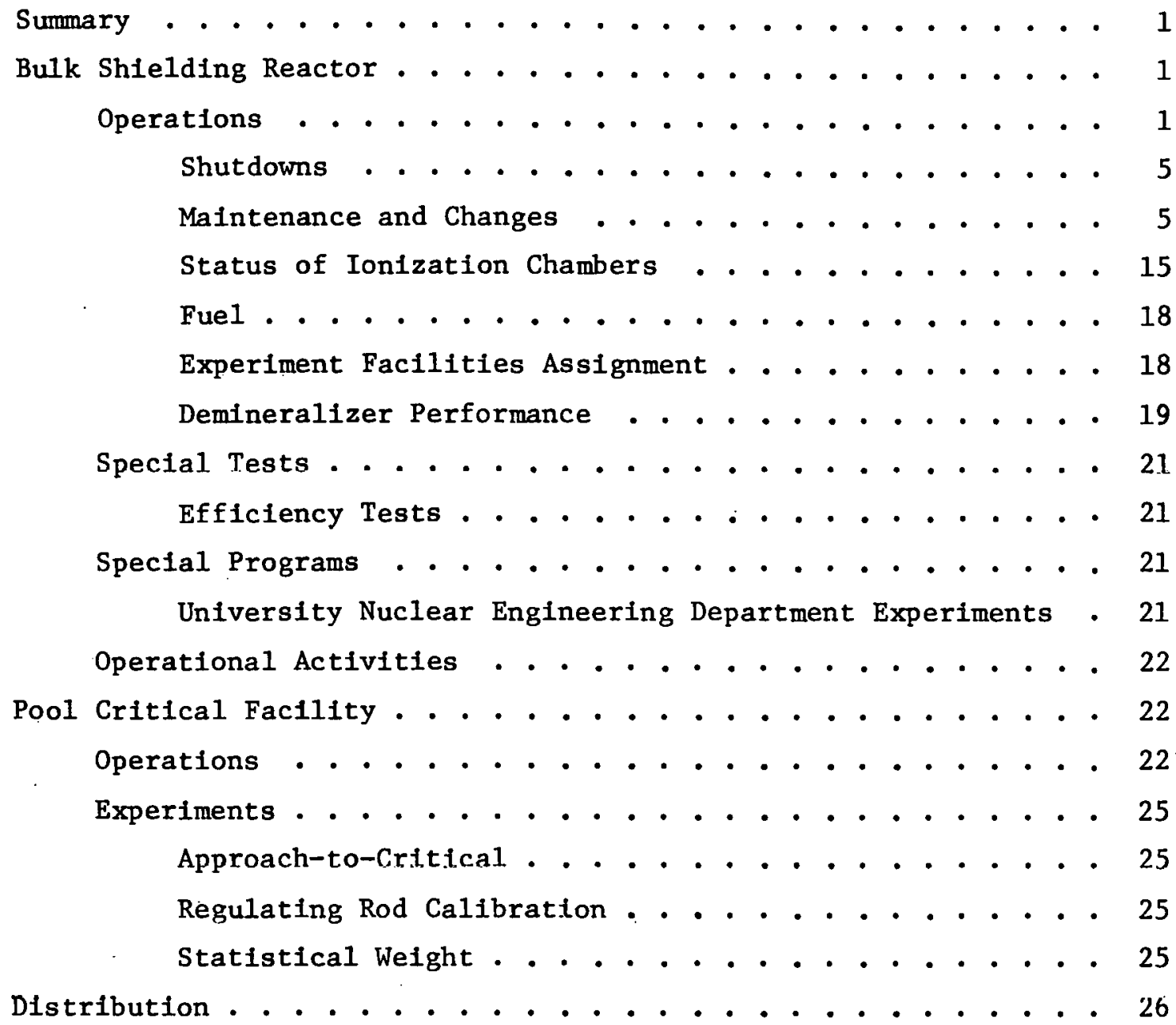


SIMMARY

The BSR operated at an average power leve1 of $1,637 \mathrm{~kW}$ for $50.05 \%$ of the time during July, August, and September. Water-quality control in both the reactor primary and secondary cooling systems was satisfactory.

The BSR was operated at low and variable power during this quarter for 27.327 hours as part of the training programs for nuclear reactor operator trainees from Memphis State University.

The PCA was also used in the above-mentioned training programs and was operated on six occasions when the Oak Ridge Associated Universities or Memphis State University students actively participated in training laboratories.

\section{BULK SHIELDING REACTOR}

Operations

During this quarter, the reactor operated $50.05 \%$ of the time primarily for the irradiation of research experiments. It was operated at low and variable power (2.47\% of the operating time) to enable nuclear reactor operator trainees from Memphis State University to perform training labs described elsewhere in this report. Basic operating data for this pertod are given in Table 1 . 
Table 1. Basic Operating Data (July, August, and September of 1976)

\begin{tabular}{lrcr}
\hline & $\begin{array}{c}\text { This } \\
\text { Quarter }\end{array}$ & $\begin{array}{c}\text { Last } \\
\text { Quarter }\end{array}$ & $\begin{array}{c}\text { Year } \\
\text { To Date }\end{array}$ \\
\hline $\begin{array}{l}\text { Total energy, kWd } \\
\text { Average power, } \\
\text { kW/operating hr }\end{array}$ & 75,365 & 50,301 & 163,078 \\
Time operating, \% & 1,637 & 1,756 & 1,795 \\
Reactor availability, $\%$ & 50.05 & 31.49 & 34.06 \\
Reactor water radioactivity, & 90.02 & 60.60 & 64.82 \\
$\quad$ counto min-1 ml=1 (av) & 1,282 & 1,349 & 1,620 \\
Reactor water resistivity, & & & \\
$\quad$ ohm-cm (av) & $1,184,000$ & $1,109,000$ & $1,080,000$ \\
Standard fuel elements depleted & 0 & 0 & 0 \\
Control fuel elements depleted & 0 & 0 & 0 \\
Research samples & 30 & 50 & 116 \\
\hline
\end{tabular}

Core loading 31 (Figure 1) has been in service during this entire report period. The initial operating mass (4995 $\mathrm{g}^{235} \mathrm{U}$ ) has been reduced to $\sim 4900 \mathrm{~g}$ due to burnup, thereby reducing the excess reactivity from $5.49 \% \Delta \mathrm{k} / \mathrm{k}$ to $\sim 4.05 \% \Delta \mathrm{k} / \mathrm{k}(\sim 1.50 \% \Delta \mathrm{k} / \mathrm{k}$ excess react1vity above xenon equilibrium).

The west $\mathrm{D}_{2} \mathrm{O}$ tank was removed in September and BSR core loading No. 31 was temporarily repositioned four rows west in the grid plate using standard procedures (Figure 2). An aluminum plate was placed over the empty grid positions created by the core shift. Core 31 will be returned to the original position on the grid after completion of an experimental run at the Low Temperature Irradiation Facility. 


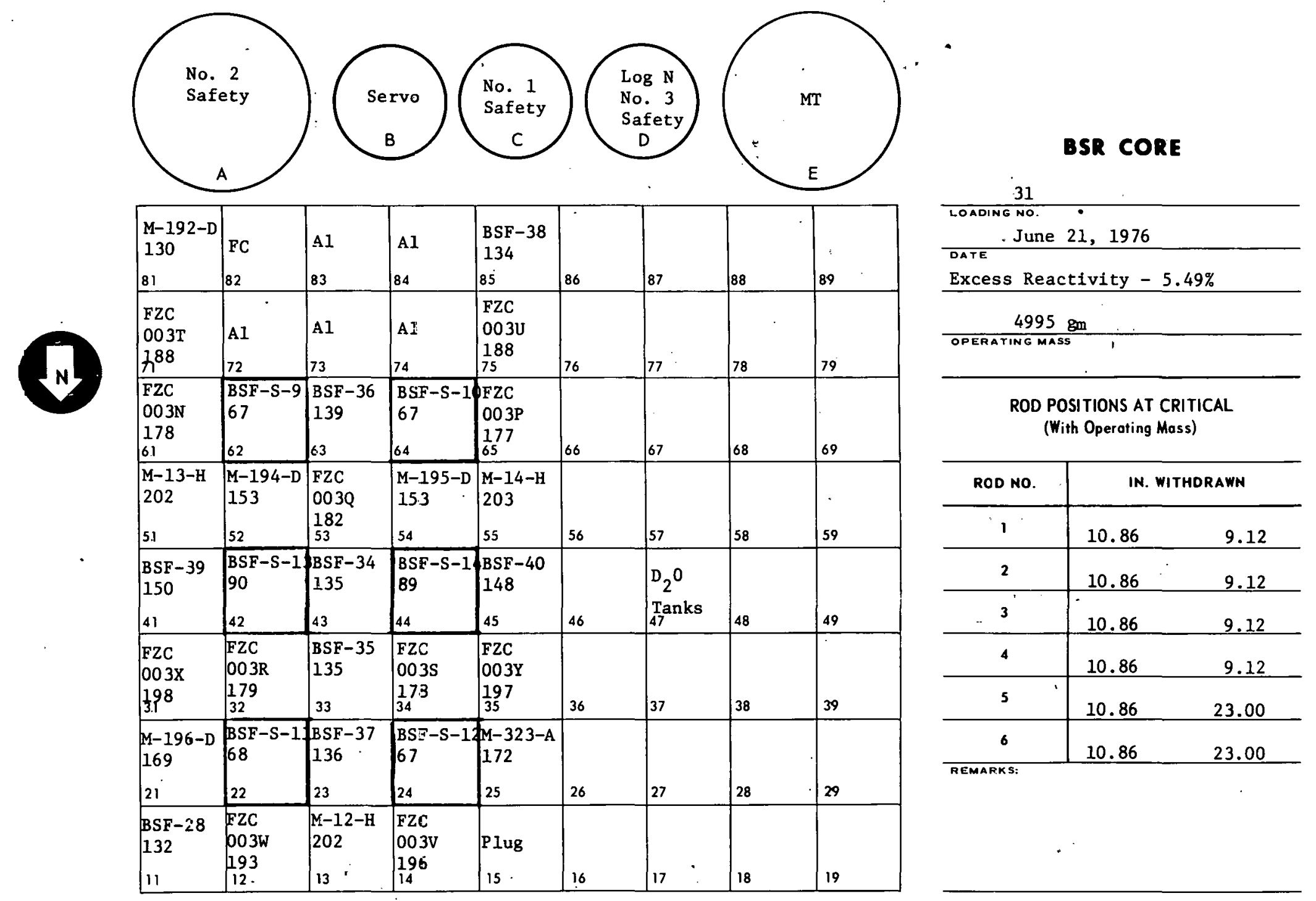

Figure 1. Core Loading 31 - BSR. 


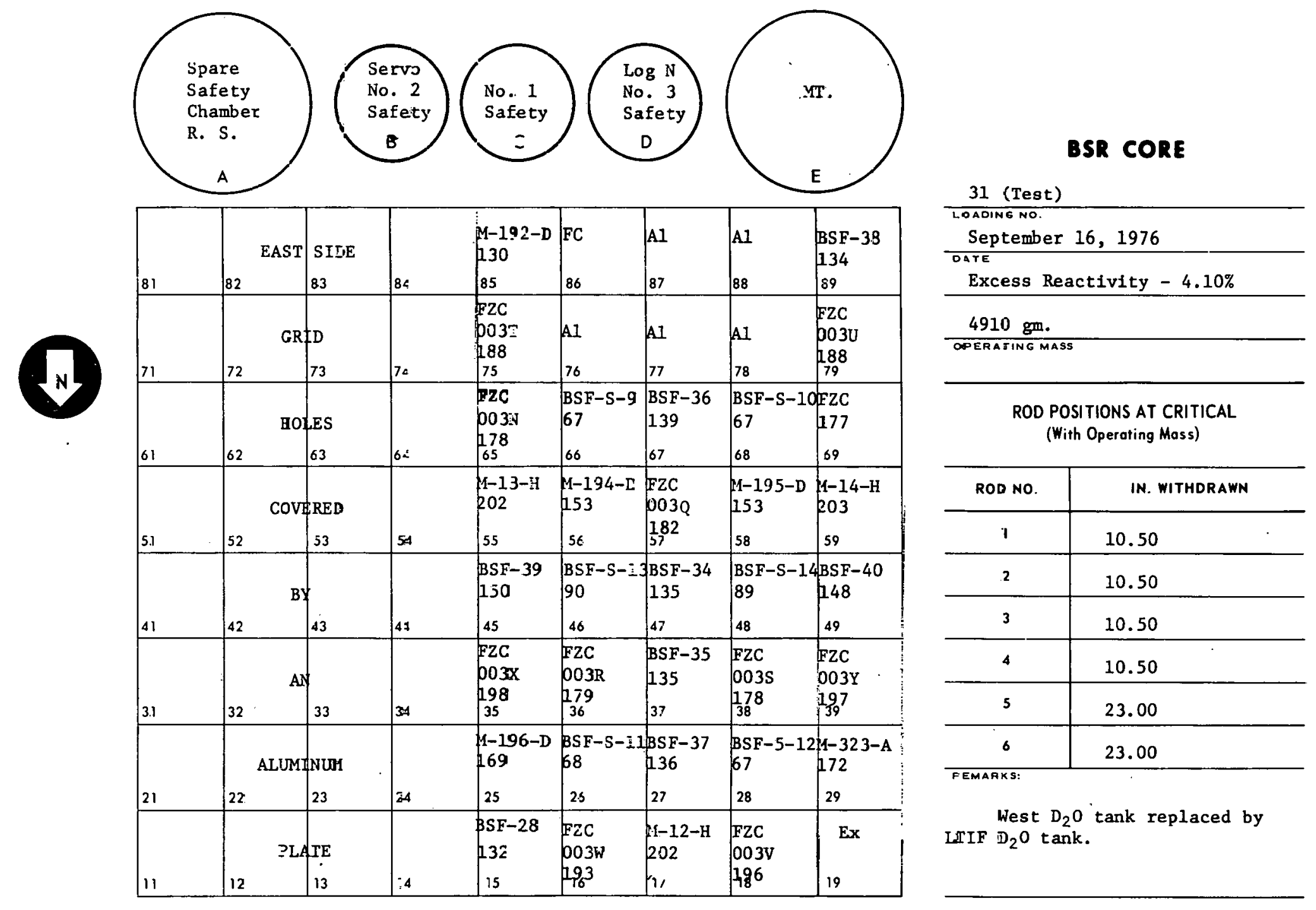

Figure 2. Core Loading 31 (Test) - BSR. 
Shutdowns

There was one unscheduled shutdown during the quarter from an LTIF experiment setback. Table 2 gives an analysis of both scheduled and unscheduled shutdowns.

Table 2. Analysis of Shutdowns

\begin{tabular}{|c|c|c|}
\hline Description of Shut down & Number & $\begin{array}{c}\text { Downtime } \\
\text { (hrs) }\end{array}$ \\
\hline \multicolumn{3}{|l|}{ Scheduled } \\
\hline \multicolumn{3}{|l|}{ Experimenters: } \\
\hline No request to operate & 14 & 517.466 \\
\hline Experiment insertion or removal & 8 & 365.083 \\
\hline Repositioning of the reactor & 3 & 3.000 \\
\hline \multicolumn{3}{|l|}{ Reactor Operations: } \\
\hline BSR quarterly shutdown & 1 & 102.600 \\
\hline $\begin{array}{l}\text { Xenon decay for repositioning Core } \\
31 \text { in grid assembly }\end{array}$ & 1 & 62.400 \\
\hline Student training & 15 & 2.740 \\
\hline Reloading critical runs & 4 & 49.400 \\
\hline Subtotal & 46 & $1,102.689$ \\
\hline Unscheduled & & \\
\hline Experimenters & 1 & 0.283 \\
\hline Reactor Operations & 0 & 0.000 \\
\hline Subtotal & 1 & 0.283 \\
\hline Total & 47 & $1,102.972$ \\
\hline
\end{tabular}

Maintenance and Changes

Changes made in the reactor control instrumentation to improve operating conditions are documented by the BSR contro1-change-memoranda system. Those changes which were made during this report pertod are listed in Table 3 .

Changes made in the mechanical systems to improve operating conditions and/or to perform special tests are documented by. the BSR mechancial design change memoranda system. Those changes which were made during this report 
period are listed in Table 4. Maintenance or changes on the instrumentation and mechanical components in the complex are listed in Tables 5, 6, and 7. Table 8 presents the status of the ionization and fission chambers. 
Table 3. Instrumentation and Controls Change Memoranda

Completed During This Report Period

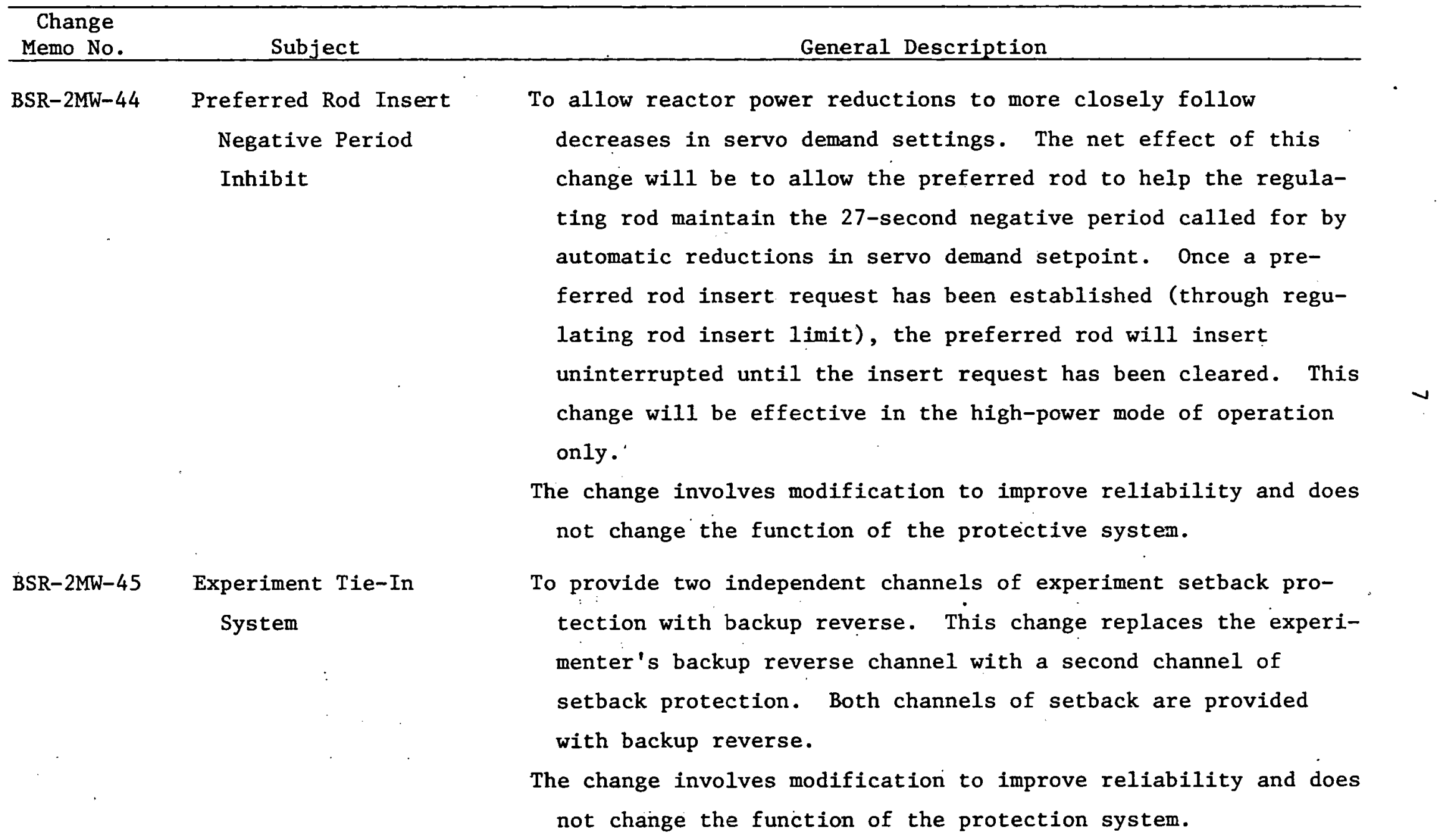


Table 3 (Continued)

\begin{tabular}{|c|c|c|}
\hline $\begin{array}{c}\text { Change } \\
\text { Memo No. }\end{array}$ & Subject & General Lescription \\
\hline BSR-2MW-46 & $\begin{array}{l}\text { BSR Pcwer Readout } \\
\text { in tie HSST } \\
\text { Experiment Cort trol } \\
\text { Roor: }\end{array}$ & $\begin{array}{l}\text { To provide the HSST experiment with a signal proportional to } \\
\text { reactor power, a } 20 \text {-chm retrensmitting slide wize was } \\
\text { installed in the piccammeter recorder and interconnecting } \\
\text { cable installed in the reactor control room and the HSST } \\
\text { experiment control rcom. } \\
\text { The change involves mocification to supply reactor power readout } \\
\text { to the lata logging station in the experiment control room. }\end{array}$ \\
\hline
\end{tabular}


Table 4. Mechanical Design Change Memoranda

Completed During This Report Period

\begin{tabular}{|c|c|c|}
\hline $\begin{array}{c}\text { Change } \\
\text { Memo No. }\end{array}$ & Subject & General Description \\
\hline $\begin{array}{l}\text { BSR-2MW-6, } \\
\text { Rev. } 1\end{array}$ & $\begin{array}{l}\text { Modification to Inlet } \\
\text { Manifold and Protection } \\
\text { Bar for the Core } \Delta T\end{array}$ & $\begin{array}{l}\text { The capped end of the aluminum inlet manifold extended } \\
2.125 \text { inches beyond the west } \mathrm{D}_{2} \mathrm{O} \text { tank. To allow } \\
\text { proper alfgnment between the west } \mathrm{D}_{2} \mathrm{O} \text { tank and the } \\
\text { stationary } \mathrm{D}_{2} \mathrm{O} \text { tank (originally the east } \mathrm{D}_{2} \mathrm{O} \text { tank), } \\
\text { the excess part of the inlet manifold and protection } \\
\text { bar was sawed off even with the west } \mathrm{D}_{2} \mathrm{O} \text { tank and re- } \\
\text { capped. }\end{array}$ \\
\hline
\end{tabular}


Table 5. Maintenance and Changes, Instrumentation and Controls

\begin{tabular}{|c|c|c|c|}
\hline Date & Component & Trouble or Change & Reason or Maintenazce \\
\hline $7-16-76$ & Public-address system & Inoperative. & The amplifier was retubed. \\
\hline $7-22-76$ & $\begin{array}{l}\text { No. } 3 \text { safety and } 2 \mathrm{cg}-\mathrm{N} \\
\text { channel (dual 1ori- } \\
\text { zation chamber } 2 \mathrm{CP}- \\
\text { III-106-A, SN-72-2) }\end{array}$ & $\begin{array}{l}\text { The chamber was re- } \\
\text { positionid and the } \\
\text { safety section cali- } \\
\text { brated with a change } \\
\text { of resistors as per } \\
\text { procedur } \geq \text { IPC-3. }\end{array}$ & $\begin{array}{l}\text { To ackieve proper trackizg and } \\
\text { readout agreement between the two } \\
\text { channels. }\end{array}$ \\
\hline $7-22-76$ & $\begin{array}{l}\text { Secondary } \mathrm{pH} \text { contral } \\
\text { system }\end{array}$ & $\begin{array}{l}\text { Faulty action of con- } \\
\text { troller ApHRC-14. }\end{array}$ & $\begin{array}{l}\text { An existing switch in the control- } \\
\text { ler, which cuts the current off } \\
\text { to the acid motor when the } \mathrm{pH} \\
\text { decreases } \leq 5.3 \text {, was activated. }\end{array}$ \\
\hline $7-29-76$ & Counting rate channel & Erratic. & $\begin{array}{l}\text { Replaced an electronic tube in the } \\
\text { count rate meter. }\end{array}$ \\
\hline $8-6-76$ & $\begin{array}{l}\text { Facility radiation } \\
\text { and contamination } \\
\text { monitoring syster }\end{array}$ & Poutine. & Bimonthly checkout. \\
\hline $\begin{array}{l}8-16-76 \\
\text { thru } \\
8-20-76\end{array}$ & Instrumentation & Routine. & Quarterly checks. \\
\hline
\end{tabular}


Table 5. (continued)

\begin{tabular}{|c|c|c|c|}
\hline Date & Component & Trouble or Change & Reason or Maintenance \\
\hline $8-18-76$ & Reactor $\Delta \mathrm{P}$ & $\begin{array}{l}\text { Alarm and scram set- } \\
\text { point changes. }\end{array}$ & $\begin{array}{l}\text { Due to changes in the core con- } \\
\text { figuration (i.e., } 27 \text { fuel ele- } \\
\text { ments and } 6 \text { shim rods in Core } 31 \text { ) } \\
\text { the } \Delta \mathrm{P} \text { setpoints were changed } \\
\text { corresponding with the flow set- } \\
\text { points as follows: } \\
3.4 \text { psig ( } 850 \mathrm{gpm} \text { ) alarm } \\
2.7 \text { psig ( } 750 \mathrm{gpm}) \text { scram. }\end{array}$ \\
\hline $8-19-76$ & $\Delta \mathrm{T}$ thermohms & $\begin{array}{l}\text { Inlet thermohm } \\
\text { resistance to ground } \\
\text { checked low. }\end{array}$ & $\begin{array}{l}\text { The inlet and exit thermohms were } \\
\text { replaced and calibrated with } \\
\text { satisfactory results. }\end{array}$ \\
\hline $\begin{array}{l}8-26-76 \\
\text { and } \\
8-27-76\end{array}$ & Public-address system & Signal distorted. & $\begin{array}{l}\text { Temporarily replaced the ampli- } \\
\text { fier with a spare unit until the } \\
\text { original could be repaired in the } \\
\text { shop and returned to service. }\end{array}$ \\
\hline $8-30-76$ & $\begin{array}{l}\text { Reactor outlet tem- } \\
\text { perature thermo- } \\
\text { couple }\end{array}$ & $\begin{array}{l}\text { A new outlet tempera- } \\
\text { ture thermocouple } \\
\text { was installed. }\end{array}$ & $\begin{array}{l}\text { To check if temperature readout was } \\
\text { correct. The readout agreed with } \\
\text { the original thermocouple. }\end{array}$ \\
\hline
\end{tabular}


Table 5. (continued)

\begin{tabular}{|c|c|c|c|}
\hline Date & Component & Trouble or Change & Reason or Maintenance \\
\hline $8-30-76$ & $\begin{array}{l}\text { Dual ionization chamber } \\
\text { PCP-III-106, SN-72-1 }\end{array}$ & $\begin{array}{l}\text { Being used as servo } \\
\text { chamber cnly in } \\
\text { Pcsition B. Con- } \\
\text { nected the uncom- } \\
\text { pensated section ta } \\
2 \text { safety chamber. }\end{array}$ & $\begin{array}{l}\text { Saturation characteristics checks were } \\
\text { satisfactory. The chamber CTC-3 } \\
\text { (J-118) in Position A previously } \\
\text { being used as No. } 2 \text { safety now be- } \\
\text { comes a spare chamber. }\end{array}$ \\
\hline $9-8-76$ & $\Delta \mathrm{T}$ therriohms & Calibration reckeck. & $\begin{array}{l}\text { The tiermohms were removed and the } \\
\text { calioration of the complete } \Delta T \\
\text { system was rechecked. Results } \\
\text { were satisfactory. }\end{array}$ \\
\hline $9-9-76$ & $\begin{array}{l}\text { Reactor outlet tem- } \\
\text { peratire thermo- } \\
\text { couple }\end{array}$ & $\begin{array}{l}\text { An additional thermo- } \\
\text { couple was installed } \\
\text { in the outlet water } \\
\text { line near the outlet } \\
\Delta T \text { thermoh. }\end{array}$ & $\begin{array}{l}\text { The originally installed thermocouple } \\
\text { is located off-center in the plenum } \\
\text { below the core and indicates var- } \\
\text {-iable outlet water temperature } \\
\text { depending upon the core config- } \\
\text { uration. The location of a thermo- } \\
\text { couple in the outlet water line } \\
\text { gives a dependable temperature read- } \\
\text { out since it indicates the temper- } \\
\text { ature of all of the water that has } \\
\text { passed through the core. }\end{array}$ \\
\hline
\end{tabular}


Table 6 . Maintenance and Changes, Mechanical System

\begin{tabular}{|c|c|c|c|}
\hline Date & Component & Trouble or Change & Reason or Maintenance \\
\hline $8-18-76$ & $\begin{array}{l}\text { Reactor secondary tower, } \\
\text { north fan }\end{array}$ & Coupling slipping. & $\begin{array}{l}\text { Replaced the rotor, seals and } 61 / 2 \\
\text { lbs of stainless steel shot in } \\
\text { the Dodge Flexidyne coupling to } \\
\text { correct the trouble. }\end{array}$ \\
\hline $9-15-76$ & $\begin{array}{l}\text { Shim-rod drive assenbly } \\
\text { No. } 6\end{array}$ & $\begin{array}{l}\text { Sluggish action of } \\
\text { the clutch switch. }\end{array}$ & $\begin{array}{l}\text { With the rod drive unit removed, } \\
\text { the push rod on the clutch switch } \\
\text { was cleaned to correct the trouble. }\end{array}$ \\
\hline
\end{tabular}


Table 7. Maintenance and Changes, Process System

\begin{tabular}{|c|c|c|c|}
\hline Date & Component & Trouble or Change & Reason or Main Eenance \\
\hline $8-11-76$ & $\Delta \mathrm{T}$ inlet nanifold & $\begin{array}{l}\text { Proper alignment between the } \\
\text { two } \mathrm{D}_{2} \mathrm{O} \text { tanks on the west } \\
\text { side of the core was pre- } \\
\text { vented by the end of the } \\
\text { inlet manifold and protec- } \\
\text { tion bar. }\end{array}$ & $\begin{array}{l}\text { The protection bar and capped } \\
\text { end of the inlet manifold } \\
\text { were sawed off even with the } \\
\text { west } \mathrm{D}_{2} \mathrm{n} \text { tank and the end of } \\
\text { inlet manifold recapped in } \\
\text { accordance with Mechanical } \\
\text { Design Change Memo No. BSR- } \\
\text { 2MW-6-Rev. } 1 \text {. }\end{array}$ \\
\hline $9-3-76$ & $\begin{array}{l}\text { Secondary tower } \\
\text { basin ccrrosion } \\
\text { sample rolder }\end{array}$ & $\begin{array}{l}\text { Installed a new PVC sample } \\
\text { holder. }\end{array}$ & $\begin{array}{l}\text { Routine replacement of a rusted } \\
\text { pipe sample holder. }\end{array}$ \\
\hline $9-30-76$ & Skimmer pump & Faul-y pump notor bearings. & The motor was rep_aced. \\
\hline
\end{tabular}


Table 8. Status of Ionization Chambers

\begin{tabular}{|c|c|c|c|c|}
\hline $\begin{array}{c}\text { Chamber } \\
\text { Serial No. } \\
\end{array}$ & Location & $\begin{array}{l}\text { Date } \\
\text { Present } \\
\text { Service } \\
\text { Started } \\
\end{array}$ & $\begin{array}{l}\text { Previous } \\
\text { Service }\end{array}$ & Remarks \\
\hline \multicolumn{5}{|c|}{ Chambers in Service } \\
\hline $\begin{array}{l}\text { PCP-III-106, } \\
\text { SN-72-1 }\end{array}$ & $\begin{array}{l}\text { Position } B \text {, servo } \\
\text { and No. } 2 \text { safety }\end{array}$ & $5-12-75$ & None & $\begin{array}{l}\text { This new chamber was installed in } \\
\text { the BSR in May, } 1975 .\end{array}$ \\
\hline CTC-4 (C-771) & $\begin{array}{l}\text { Position } C \text {, No. } 1 \\
\text { safety }\end{array}$ & $12-1-69$ & LITR & $\begin{array}{l}\text { The chamber was modifled for under- } \\
\text { water service in } 1969 \text {. }\end{array}$ \\
\hline $\begin{array}{l}\text { PCP-III-106A, } \\
\text { SN-72-2 }\end{array}$ & $\begin{array}{l}\text { Position } D, \text { Log-N } \\
\text { and No. } 3 \text { safety }\end{array}$ & $11-13-73$ & None & $\begin{array}{l}\text { This new dual chamber was installed } \\
\text { in the BSR in November, } 1973 .\end{array}$ \\
\hline \multirow[t]{2}{*}{$C-1045$} & $\begin{array}{l}\mathrm{CP}-81 \text {, fission } \\
\text { chamber }\end{array}$ & $10-1-69$ & PCA & $\begin{array}{l}\text { This fission chamber assembly was } \\
\text { transferred to the BSR from the } \\
\text { PCA in October, } 1969 .\end{array}$ \\
\hline & & \multicolumn{2}{|c|}{ Chambers Not in Service } & \\
\hline CTC $-3(\mathrm{~J}-118)$ & Position A, spare & $\cdot$ & $\begin{array}{l}\text { LITR and } \\
\qquad \text { BSR }\end{array}$ & $\begin{array}{l}\text { The chamber was modified for under- } \\
\text { water service in } 1969 \text {. Removed } \\
\text { from service as BSR No. } 2 \text { safety } \\
\text { in August, } 1976 \text {. }\end{array}$ \\
\hline
\end{tabular}


Tatle 8. (continued)

\begin{tabular}{|c|c|c|c|c|}
\hline $\begin{array}{c}\text { Chamber } \\
\text { Seria1 No. } \\
\end{array}$ & Lacation & $\begin{array}{l}\quad \text { Dlate } \\
\text { Present } \\
\text { Service } \\
\text { Started } \\
\end{array}$ & $\begin{array}{l}\text { Previous } \\
\text { Service }\end{array}$ & F.emarks \\
\hline $\begin{array}{l}\text { PCP (old type, } \\
\text { no serial } \\
\text { number) }\end{array}$ & Warehouse storage & & BSR & $\begin{array}{l}\text { This chamier is of the old type and } \\
\text { will te repaired if needed. }\end{array}$ \\
\hline CIC (No. 62) & BSR storage & & BSR & $\begin{array}{l}\text { This chember is reserved for the PCA } \\
\text { but can te used in an emergency } \\
\text { for the ESR. }\end{array}$ \\
\hline CIC (No. 63) & BSR storage & & BSR & $\begin{array}{l}\text { This chanber is reserved for the PCA } \\
\text { bot can be used in an emergency for } \\
\text { the } B \subseteq R \text {. }\end{array}$ \\
\hline $\begin{array}{c}\text { PCP }(Q 975, \\
\text { No. } 2)\end{array}$ & BSR storage & & BSR & $\begin{array}{l}\text { This chamber is reserved for the PCA } \\
\text { but can be ised in an emergency for } \\
\text { the } B \subseteq R \text {. }\end{array}$ \\
\hline $\begin{array}{c}\text { PCP-III-106, } \\
\text { SN-66-1 }\end{array}$ & BSR storage & & BSR & $\begin{array}{l}\text { Used as No. } 2 \text { safety and servo, } \\
\text { Safety section failed in June, } 1969 ; \\
\text { servo section failed in May, } 1975 .\end{array}$ \\
\hline
\end{tabular}


Table 8. (continued)

\begin{tabular}{|c|c|c|c|c|}
\hline $\begin{array}{r}\text { Chamber } \\
\text { Serial No. } \\
\end{array}$ & Location & $\begin{array}{l}\text { Date } \\
\text { Present } \\
\text { Service } \\
\text { Started } \\
\end{array}$ & $\begin{array}{l}\text { Previous } \\
\text { Service }\end{array}$ & Remarks \\
\hline $\begin{array}{l}\text { PCP-III-106, } \\
\quad \text { SN-66-3 }\end{array}$ & $\begin{array}{l}\text { ORR beam tube } \\
\text { storage }\end{array}$ & & $\begin{array}{l}\text { BSR and } \\
\text { ORR }\end{array}$ & $\begin{array}{l}\text { Used BSR and ORR } 1967 \text { through } \\
\text { 1973. Last removed November, } \\
\text { 1973. }\end{array}$ \\
\hline $\begin{array}{l}\text { PCP-III-106, } \\
\quad \text { SN-66-4 }\end{array}$ & ORR instrument shop & & BSR & $\begin{array}{l}\text { Used in the BSR from } 1968 \text { to } \\
\text { January, 1973. Repaired in } 1969 .\end{array}$ \\
\hline
\end{tabular}


Fuel

There were no changes in the number of components in the fuel inventory; however, the fuel inventory is listed in Table 9.

Table 9. Fuel and Shim Rod Status

\begin{tabular}{|c|c|c|c|}
\hline & $\begin{array}{c}\text { Th1s } \\
\text { Quarter }\end{array}$ & $\begin{array}{c}\text { Last } \\
\text { Quarter }\end{array}$ & $\begin{array}{c}\text { Year } \\
\text { To Date }\end{array}$ \\
\hline Fuel elements depleted & 0 & 0 & 0 \\
\hline Control-rod fuel elements depleted & 0 & 0 & 0 \\
\hline New fuel elements placed in service & o & 3 & 5 \\
\hline $\begin{array}{l}\text { New control-rod fuel elements placed } \\
\text { in service }\end{array}$ & 0 & 0 & 0 \\
\hline New fuel elements available for use & 6 & 6 & 6 \\
\hline $\begin{array}{l}\text { New control-rod fuel elements } \\
\text { avallable for use }\end{array}$ & 6 & 6 & 6 \\
\hline $\begin{array}{l}\text { Partially depleted fuel elements } \\
\text { available for use }\end{array}$ & 2 & 2 & 2 \\
\hline New shim rods placed in service & 0 & 0 & 0 \\
\hline Boron stainless steel shim rods in use & 6 & 6 & 6 \\
\hline $\begin{array}{l}\text { Boron stainless steel shim rods } \\
\text { available for use }\end{array}$ & 2 & 2 & 2 \\
\hline
\end{tabular}

Experiment Facilities Assignment

Facility assignments are listed in Table 10. The tubes of the stationary $\mathrm{D}_{2} \mathrm{O}$ tank are not permanently assigned; they are used by various Laboratory personnel for short term sample irradiations. 
Table 10. Facilities Assignment

\begin{tabular}{|c|c|c|}
\hline Facility & Location & $\begin{array}{c}\text { Division or } \\
\text { Sponsor }\end{array}$ \\
\hline Liquid helium cryostat & $\begin{array}{l}\text { Southwest corner. of pool } \\
\text { using west } \mathrm{D}_{2} \mathrm{O} \text { tank }\end{array}$ & Solid State \\
\hline Liquid nitrogen cryostat & On instrument bridge & Solid State \\
\hline Ambient temperature factlity & North face of core & Solid State \\
\hline Front-face tube & North face of core & Solid State \\
\hline Fast-neutron tube & Core position 15 & Solid State \\
\hline Water-cooled tube & Core position 11 & Solid State \\
\hline $\begin{array}{l}\text { Dry thermal-neutron tubes* } \\
(\mathrm{N}-4 \text { and } \mathrm{S}-3)\end{array}$ & Stationary $\mathrm{D}_{2} \mathrm{O}$ tank & Operations \\
\hline $\begin{array}{l}\text { Dry thermal-neutron tubes* } \\
\text { (east, center, southwest, } \\
\text { and northwest) }\end{array}$ & Stationary $\mathrm{D}_{2} \mathrm{O}$ tank & Operations \\
\hline
\end{tabular}

\section{Demineralizer Performance}

Table 11 gives detailed information on the condition of the primary water system for the preceding years and pertinent data on the performance of the bypass demineralizer. 
Table 11. Tlemineralizer Performance Data

\begin{tabular}{|c|c|c|c|c|c|c|c|c|c|}
\hline $\begin{array}{l}\text { Ruin } \\
\text { No. }\end{array}$ & $\begin{array}{c}\text { Initiation } \\
\text { Date } \\
\end{array}$ & $\begin{array}{c}\text { Termination } \\
\text { Date }\end{array}$ & $\begin{array}{l}\text { Throughput } \\
\text { (gallons) }\end{array}$ & \multicolumn{2}{|c|}{$\begin{array}{c}\text { Gross Gamma } \\
\text { (counts } \min ^{-1} \mathrm{ml}^{-1} \text { ) }\end{array}$} & \multicolumn{2}{|c|}{$\mathrm{pH}$} & \multicolumn{2}{|c|}{$\begin{array}{l}\text { Specific Resistance } \\
\text { (ohm }-\mathrm{cm}\end{array}$} \\
\hline 33 & $1-4-73$ & $3-5-73$ & $1.514,000$ & 1,280 & 115 & 5.7 & 5.8 & $=1,008,000$ & $1,430,000$ \\
\hline 34 & $3-6-73$ & $4-30-73$ & $1, .393,200$ & 1,848 & 181 & 5.7 & 5.7 & 873,000 & $1,363,000$ \\
\hline 35 & $5-2-73$ & $7-2-73$ & $2,360,000$ & 2,072 & 120 & 5.8 & 5.8 & 896,000 & $1,209,000$ \\
\hline 36 & $7-3-73$ & $9-4-73$ & $1,700,000$ & 1,672 & 116 & 5.8 & 5.8 & 792,000 & $1,270,000$ \\
\hline 38 & $11-14-73$ & $1-7-74$ & $1,592,000$ & 1,353 & 98 & 5.7 & $5 . ?$ & 738,000 & $1,102,000$ \\
\hline 39 & $1-9-74$ & $3-13-74$ & $1,320,000$ & 1.931 & 101 & 6.2 & 6.0 & 666,000 & 908,000 \\
\hline $40 *$ & $3-15-74$ & $7-30-74$ & $1,400,000$ & 9 & 0 & 6.2 & 6.0 & 364,000 & $1,132,000$ \\
\hline 41 & $8-16-74$ & $12-4-74$ & $1,500,000$ & 2,316 & 385 & 5.8 & 5.8 & 630,000 & 895,000 \\
\hline 45 & $11-5-75$ & $4-29-76$ & $2,325,000$ & 2,146 & 154 & 5.3 & 5.5 & 902,000 & $1,593,000$ \\
\hline 46 & $4-30-76$ & $9-2-76$ & $2,300,000$ & 1,430 & 124 & 5.4 & 5.6 & $1,085,000$ & $1,808,000$ \\
\hline 47 & $9-2-76$ & In Service & 775,000 & 1,282 & 96 & 5.5 & 5.7 & $1,184,000$ & $2,067,000$ \\
\hline
\end{tabular}

*The reactor was shut down durirg the entire run.

**New resin in the demineralizer colums 


\section{Special Tests}

\section{Efficiency Tests}

Tests were performed by Inspection Engineering on the cell ventilation filters. Details are given in Table 12.

Table 12. Efficiency Tests Results, Filters

\begin{tabular}{lccc}
\hline Date & Unit & Type Test & $\begin{array}{c}\text { Efficiency } \\
(\%)\end{array}$ \\
\hline 8-19-76 & North Bank & Elemental Iodine & 99.94 \\
$9-16-76$ & South Bank & Elemental Iodine & 99.83 \\
\hline
\end{tabular}

Special Programs

The University Nuclear Engineering Department Experiments

The BSR was used for a training lab for nuclear reactor operator trainees as described below:

Xenon Buildup and Decay Experiment. - On July 1, 1976, following operation at 2 MW to achieve xenon equilibrium, the power level of the BSR was reduced to $4 \mathrm{~kW}$ to begin an experiment for students from Memphis State University to study the buildup and decay of xenon in the BSR core. The students performed all activities assoclated with the experiment under the direct supervision of an Operations Division supervisor. The experiment, performed on a 24-hr-day scheduled until completion on July 2, 1976, was an exercise in: (1) maintalning the reactor critical at $4 \mathrm{~kW}$; (2) determining the reactivity worth of a shim rod under varying concentrations of xenon; and (3) determining the reactivity worth of xenon in the core as a function of time. 
Operational Activities

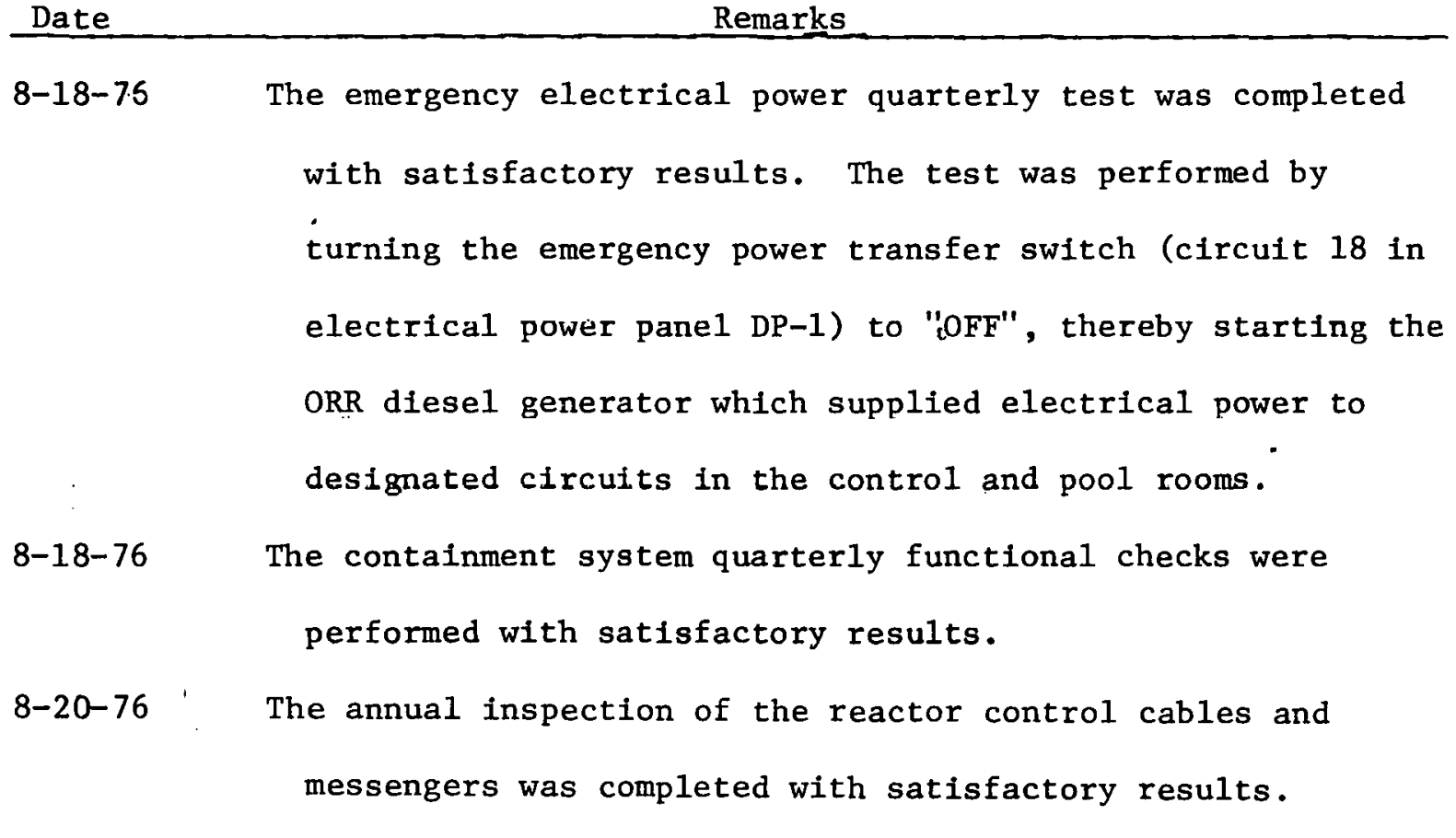

POOL CRTTICAI ASSEMBLY

Operations

The PCA was used 49.3 hours as a training facility for the benefit of nuclear reactor operator trainees from Memphis State University and personnel trom the Uak Kidge Associated Universities. Uperational activities in preparing the facility for use included a checkout of the reactor control instrumentation and preparation of the required loadings. The operational activities are 1isted in Table 13 (Usage of Pool Critical Facility). The PCA maintenance is listed in Table 14. 
Table 13. Usage of Pool Critical Facility

\begin{tabular}{|c|c|c|c|}
\hline Date & Operational Activity & Purpose & $\begin{array}{l}\text { Hours } \\
\text { Used }\end{array}$ \\
\hline $\begin{array}{l}7-1-76 \\
\text { and } \\
7-2-76\end{array}$ & $\begin{array}{l}\text { Estatlished Core No. } 77 \text { to permit cali- } \\
\text { bration of the regulating rod and the } \\
\text { performance of the importance function } \\
\text { experiment. }\end{array}$ & $\begin{array}{l}\text { Training lab for Memphis } \\
\text { State University students. }\end{array}$ & 16.1 \\
\hline $\begin{array}{l}8-2-76 \\
\text { and } \\
8-3-76\end{array}$ & $\begin{array}{l}\text { Established Cores No. } 187 \text { and } 188 \text { to } \\
\text { obtain a critical mass following the } \\
\text { standard approach-to-critical } \\
\text { procedure. }\end{array}$ & $\begin{array}{l}\text { Training lab for Oak Ridge } \\
\text { Associated Universities } \\
\text { personnel. }\end{array}$ & 19.5 \\
\hline $\begin{array}{l}8-4-76 \\
\text { and } \\
8-5-76\end{array}$ & $\begin{array}{l}\text { Established Core No. } 77 \text { to permit cali- } \\
\text { bration of the regulating rod and the } \\
\text { performance of the importance function } \\
\text { experiment. }\end{array}$ & $\begin{array}{l}\text { Training lab for Oak Ridge } \\
\text { Associated Universities } \\
\text { personnel. }\end{array}$ & 13.7 \\
\hline
\end{tabular}


Table 14. PCA Maintenance

\begin{tabular}{lccc}
\hline Date & Component & $\begin{array}{c}\text { Trouble } \\
\text { or Condition }\end{array}$ & Action \\
\hline 7-29-76 & $\begin{array}{c}\text { No. } 2 \text { control rod } \\
\text { drive assembly }\end{array}$ & $\begin{array}{c}\text { Malfunction of the } \\
\text { clutch switch }\end{array}$ & $\begin{array}{c}\text { The drive unit was removed.and the clutch } \\
\text { switch push rod cleaned. }\end{array}$ \\
\hline
\end{tabular}




\section{Experiments}

Experiments were conducted at the PCA by students from the Nuclear Engineering Departments of Memphis State University and Oak Ridge Assoclated Universities as Indicated in Table 13. These experiments are described briefly and were directly supervised by the training supervisor of the Operations Division.

Approach-to-Critical

To demonstrate the technique of assembling a reactor core, a critical mass was loaded by the trainees following the standard approach-tocritical procedure.

\section{Regulating-Rod Calibration}

A technique used in callbrating reactor control rods was demonstrated by using the perlod method in calibrating the regulating rod. The exercise was performed by the trainees.

\section{$\underline{\text { Statistical Weight }}$}

An experiment was performed to determine the effect of absorbers on the reactivity as a function of position in a special fuel element located in the reactor core. Using guidelines provided by the Operations Division supervisor, the experiment was performed by the trainees. 
THIS PAGE

\section{WAS INTENTIONALLY LEFT BLANK}


1. R. G. Berggren

2. G. H. Burger

3. C. D. Cagle

4. W. R. Casto

5. J. W. Cleland

6. G. H. Coleman

7. R. R. Coltman, Jr.

8. J. A. Conlin

9. J. A. Cox

10. W. A. Duggins

11. E. D. Gupton

12. T. P. Hamrick

13. S. S. Hurt, III

14. L. P. Jernigan

15. E. B. Johnson

16. E. D. Lance

17. D. L. Laughlin

18. R. V. McCord

19. F. H. Neil1

20. T. B. Nixon

21. L. C. Oakes

22. J. H. Pemberton

23. H. Postma

24. M. E. Ramsey

25. W. H. Sides

26-27. J. R. Thomas

28. K. W. West

29. M. K. Wilkinson

30. F. W. Young

31-32. Laboratory Records Department

33. Laboratory Records, ORNL R.C.

34-35. Central Research Library

36. Research and Technical Support Division

37. ORNL Patent Office

\section{EXTERNAL DISTRIBUTION}

38. K. M. Akhtar, Head, Reactor Operations Maintenance Division, Pakistan Institute of Nuclear Science and Technology, Post Office Nilore, Rawalpindi, Pakistan

39. R. D. Martin, Ford Nuclear Reactor, University of Michigan, 2301 Bonisteel Boulevard, Ann Arbor, Michigan

40. J. D. Randall, Director, Nuclear Science Center, Texas A\&M University, College Station, Texas 77843.

41. D. Segal, Israel

42-43. E. S. Beckjord, Division of Reactor Development and Demonstration, ERDA, Washington, D. C.

44. Safety and Environmental Control Division, ERDA-ORO

45-71. 'lechnical Information Center, Oak Ridge 